\title{
Vitamin D and juvenile idiopathic arthritis
}

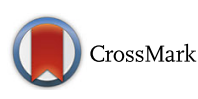

\author{
Sarah L. Finch ${ }^{1}$, Alan M. Rosenberg ${ }^{2}$ and Hassan Vatanparast ${ }^{3^{*}}$ (D)
}

\begin{abstract}
Background: Vitamin D has been implicated in the pathogenesis of autoimmune diseases. While the roles of vitamin $D$ in other autoimmune diseases have been investigated, less is known about the role of vitamin $D$ in chronic childhood arthritis.

Main body: This review summarizes and evaluates evidence relating to 25 -hydroxyvitamin D (25(OH)D) and chronic childhood arthritis. A scoping literature review was conducted using Ovid Medline, Ovid Embase, Cumulative Index to Nursing and Allied Health Literature, Web of Science and Scopus. Further, we geo-mapped the results of the studies to identify the patterns of the association between vitamin $\mathrm{D}$ and chronic childhood arthritis across the globe. Of 38 studies reporting $25(\mathrm{OH}) \mathrm{D}$ concentrations in childhood chronic arthritis, $32(84.2 \%)$ reported that a significant number of children had suboptimal $(<75 \mathrm{nmol} / \mathrm{L})$ status.
\end{abstract}

Conclusion: The data indicate suboptimal vitamin D status in children with chronic arthritis. Further, the association between low vitamin $\mathrm{D}$ and increased arthritis activity follow a north-south geographical gradient.

Keywords: Vitamin D, Childhood arthritis, Juvenile idiopathic arthritis

\section{Background}

Arthritis is among the most common chronic diseases in children. Juvenile Idiopathic Arthritis (JIA) is the current nomenclature applied to denote a group of clinically distinguishable subsets that share chronic, childhood-onset arthritis of unknown cause as a unifying feature. The etiologies of JIA are unknown and the pathogeneses unclear but are likely multifactorial. Among epidemiologic studies there is substantial variability in the frequencies with which JIA and its respective subtypes are reported to occur; chronic arthritis prevalence rates range from 0.07 to $4.01 / 1000$ children and annual incidences from 0.008 to $0.226 / 1000$ children [1]. Putative explanations for the disparities in reported juvenile arthritis prevalence rates include, as examples, differences in diagnostic criteria applied (specifically, JIA or the earlier Juvenile Rheumatoid Arthritis (JRA) [2] or Juvenile Chronic Arthritis (JCA) [3] classification systems) and in case ascertainment methods.

While methodologic inconsistencies among JIA epidemiologic studies might account for perceived prevalence differences, actual differences might occur as a consequence of genetic, ethnic, environmental, and lifestyle influences. Vitamin D status is potentially governed by these same

\footnotetext{
*Correspondence: vatan.h@usask.ca

${ }^{3}$ College of Pharmacy \& Nutrition and School of Public Health, University of

Saskatchewan, 104 Clinic Place, Saskatoon, SK S7N 2Z4, Canada

Full list of author information is available at the end of the article
}

factors; vitamin D receptor genotype, ethnically related skin tone and clothing, environmental variations in exposure to ultraviolet $\mathrm{B}$ radiation relating to the latitude of residence and season, and vitamin D nutritional intake are factors that modulate vitamin $\mathrm{D}$ concentrations.

As an immune and inflammatory mediator, vitamin $\mathrm{D}$ is implicated in the pathogenesis of autoimmune diseases including, as examples, multiple sclerosis, type 1 diabetes, rheumatoid arthritis, Crohn's disease, and chronic childhood arthritis [4-6]. Cells involved in innate and adaptive immune responses such as macrophages, dendritic cells, $\mathrm{T}$ cells, and B cells express enzymes required to activate and respond to vitamin D [7-9]. Cytochrome p450 27B1 (CYP27B1) is the enzyme required to synthesize 1,25-dihydroxyvitamin $\mathrm{D}(1,25(\mathrm{OH}) 2 \mathrm{D})$, the active form of vitamin $\mathrm{D}$, from circulating 25-hydroxyvitamin $\mathrm{D}$ $(25(\mathrm{OH}) \mathrm{D})$. The actions of $1,25(\mathrm{OH}) 2 \mathrm{D}$ are mediated by its binding to the vitamin $\mathrm{D}$ receptor (VDR), a nuclear transcription factor. VDR then binds to the Vitamin D Response Element (VDRE), a genetic sequence located in the promotor region of genes regulated by vitamin $\mathrm{D}[7-$ 9]. Vitamin D tends to suppress the immune response [6]. Consequently, low vitamin D concentrations are associated with an increase in pro-inflammatory mediators and more active disease $[6,10]$ consistent, for example, with the observation that low serum $25(\mathrm{OH}) \mathrm{D}$ is associated with increased disease activity in rheumatoid arthritis [11].

(c) The Author(s). 2018 Open Access This article is distributed under the terms of the Creative Commons Attribution 4.0 International License (http://creativecommons.org/licenses/by/4.0/), which permits unrestricted use, distribution, and 
Reports of relationships between vitamin D and chronic childhood arthritis are derived from studies having different methodologic approaches, originating from multiple geographic regions, and comprising demographically disparate populations. Since the last analysis of these reports in 2013 [12] the number of studies reporting $25(\mathrm{OH}) \mathrm{D}$ concentrations in children with chronic arthritis have increased from 14 to 38 . An updated, systematic analysis of pertinent literature should help to further refine understanding of the relationships between vitamin D and juvenile arthritis, contribute to optimizing management of vitamin D status in children with arthritis, and clarify vitamin D's potential role in mediating disease pathogenesis.

Scoping reviews are methodologic approaches for thoroughly distilling and synthesizing information derived from different studies having varied designs. The purposes of scoping reviews are to not only capture key concepts that can guide care but also to recognize knowledge gaps that can inspire future research priorities [13].

Although nomenclature applied to chronic childhood arthritis classification systems has changed over the years, JIA is the current terminology. For clarity, this review will hereafter use the term JIA to encompass the forms of chronic childhood arthritis also included in the JCA and JRA classification systems. However, in this review, when quoting the literature, we use the terminology for chronic childhood arthritis (JCA, JRA, or JIA) that was applicable at the time the cited reference was published [14].
Here we report the results of a vitamin D- JIA scoping review that summarizes, synthesizes, evaluates, and interprets pertinent evidence from the literature to address the following research questions: 1) What is the relationship between vitamin D status and the occurrence of JIA? 2) What is the relationship between vitamin $\mathrm{D}$ status and childhood arthritis activity? 3) What is the relationship between vitamin D status in JIA and medication use? 4) What is the relationship between vitamin D status and geographic and demographic characteristics in children with JIA?

\section{Methodology}

To ensure a comprehensive literature scan, this scoping review applied the iterative methodological framework escribed by Arksey and O'Malley, with refinements by Levac et al. and Colquhoun et al. [14-16]. Five biomedical literature search engines were accessed, in the following sequence: Medline (using Ovid), Embase (using Ovid), Cumulative Index to Nursing and Allied Health Literature (CINHAL), Web of Science, and Scopus. Reference lists within each of the publications retrieved from the web-based searches were scanned to ensure that no relevant citations were missed. Medical Subject Heading $(\mathrm{MeSH})$ terms used for retrieval were "vitamin D" and "juvenile arthritis". The search term "juvenile arthritis" was general enough to capture citations that referred to JCA, JRA and JIA classification terms (Table 1). Search results, which included published articles, letters, and abstracts

Table 1 Comparison of classification systems of chronic childhood arthritis ${ }^{a}$

\begin{tabular}{|c|c|c|c|}
\hline & $\begin{array}{l}\text { American College of } \\
\text { Rheumatology } 1977 \text { [2] }\end{array}$ & $\begin{array}{l}\text { European League Against } \\
\text { Rheumatism } 1978 \text { [3] }\end{array}$ & $\begin{array}{l}\text { International League Against } \\
\text { Rheumatism } 1994 \text { and } 2001 \text { [1] }\end{array}$ \\
\hline Classification Title & Juvenile Rheumatoid Arthritis & Juvenile Chronic Arthritis & Juvenile Idiopathic Arthritis \\
\hline Symptom duration & Minimum 6 weeks & Minimum 3 month & Minimum 6 weeks \\
\hline \multirow[t]{8}{*}{ Subtypes } & Systemic & Systemic & Systemic \\
\hline & \multirow[t]{2}{*}{ Polyarticular } & Polyarticular & Polyarthritis RF negative \\
\hline & & JRA (RF positive Polyarticular) & Polyarthritis RF positive \\
\hline & \multirow[t]{5}{*}{ Pauciarticular } & \multirow[t]{3}{*}{ Pauciarticular } & Oligoarthritis \\
\hline & & & Persistent \\
\hline & & & Extended \\
\hline & & Juvenile psoriatic & Psoriatic arthritis \\
\hline & & Juvenile ankylosing spondylitis & Enthesitis-related arthritis \\
\hline
\end{tabular}

Undifferentiated arthritis

\footnotetext{
Prior to 1997, two chronic childhood arthritis classification systems were used. The American College of Rheumatology (ACR) [2] classification criteria referred to chronic childhood arthritis as Juvenile Rheumatoid Arthritis (JRA) and the European League Against Rheumatism (EULAR) applied the term Juvenile Chronic Arthritis (JCA) [3]. Differences between the two classification systems hindered exchange and comparison of data between the two systems [61]. To reconcile differences between ACR and EULAR criteria, the International League Against Rheumatism (ILAR) JIA criteria were introduced. This table provides a comparison of diagnostic criteria [17]. The ILAR classification system defines JIA as all forms of inflammation of one or more joints beginning in children younger than age 16 years [17]. JIA is further classified into seven categories based on inclusion and exclusion criteria according to features present within the first six months of disease. The seventh category includes those who do not fit into one category, meet criteria for more than one category, or have exclusion criteria that preclude assigning a category
} 
from conference proceedings, were collated and duplicates of articles removed. Publication titles and abstracts were then screened for relevance to the subject of vitamin $\mathrm{D}$ in children with idiopathic chronic arthritis as defined by JIA, JCA, or JRA classification criteria [2, 3, 17]. The full texts of relevant articles were then reviewed.

Inclusion criteria for the review were 1) study conducted in humans, 2) 25(OH)D concentrations reported, 3) participants having a diagnosis of JCA, JRA, or JIA, and 4) JCA, JRA, JIA diagnosis without an associated coexistent autoimmune disease. Exclusion criteria were 1) study conducted in animals, 2) the presence of an associated autoimmune disease 3) pregnant or lactating subjects, 4) $25(\mathrm{OH}) \mathrm{D}$ concentrations not reported), and 5) review articles. The process applied to identify eligible articles for the review is shown in Fig. 1 [18]. Articles in any language were eligible; however, no non-English language articles without at least an English abstract were found. From all relevant articles retrieved the following information was extracted: juvenile arthritis classification system (JCA, JRA, or JIA); sample size; sex ratio; patient age (at baseline or time of study if the study was cross-sectional); geographic location (country, city, and latitude and longitude), year of study; 25(OH)D concentration; study conclusion; and, if applicable, control group sample size, characteristics, and $25(\mathrm{OH}) \mathrm{D}$ concentration. The latitudes and longitudes reported were that of the city where the study was conducted; if unavailable, the province, state or region's center latitude was used and, as a last resort, the country's central latitude was used. 25(OH)D status by season of measurement was not reported in any of the articles found and therefore could not be considered.

Geographic Information Systems (GIS) mapping was performed using ArcGIS version 10.4 to visualize studies by juvenile arthritis classification, 25(OH)D status, location, and latitude. For all reported studies, an additional map comparing the difference in $25(\mathrm{OH}) \mathrm{D}$ concentration between those reporting active versus inactive disease was made.

\section{Defining vitamin $D$ status}

Vitamin D deficiency is defined as a serum 25(OH)D concentration less than $30 \mathrm{nmol} / \mathrm{L}$, a $25(\mathrm{OH}) \mathrm{D}$ concentration between 30 and $50 \mathrm{nmol} / \mathrm{L}$ is considered insufficient, greater than $50 \mathrm{nmol} / \mathrm{L}$ is considered sufficient and a $25(\mathrm{OH}) \mathrm{D}$ status greater than $125 \mathrm{nmol} / \mathrm{L}$ is considered at risk of adverse effects [19]. These values are based on the Institute of Medicine (IOM) review of published research focused on determining the optimal vitamin D concentration for maximal calcium absorption, prevention of rickets, reduction of fracture risk and prevention of osteomalacia in healthy populations [19]. In the most recent review of vitamin $\mathrm{D}$ requirements, the IOM concluded that there was inadequate information to make intake recommendations in relation to other biologic roles of vitamin D [19]. The current recommended dietary allowances (RAD) of vitamin
D are $400 \mathrm{IU}$ from 0 to 12 months of age and $600 \mathrm{IU}$ per day from 1 to 18 years of age [19].

The Endocrine Society has published clinical practice guidelines for patients at risk of vitamin D deficiency [20]. The Society recommends that at-risk populations, including "obese children and adults and children and adults on anticonvulsant medications, glucocorticoids, antifungals such as ketoconazole, and medications for acquired immune deficiency syndrome be given at least two to three times more vitamin $\mathrm{D}$ for their age group to satisfy their body's vitamin D requirement" [20]. The optimal 25(OH)D concentration suggested by the Endocrine Society is $75 \mathrm{nmol} / \mathrm{L}$. To meet this concentration it is recommended that $400-1000$ IU be given between 0 to 12 months of age, 600-1000 IU per day from 1 to 8 years of age, and 1500-2000 IU for children between ages 9-18 years [20]. These recommendations, however, are not specific for children with chronic arthritis.

\section{Results of scoping review and discussion}

Considerations when evaluating the role of vitamin D in JIA include vitamin D requirements for this population and the role that vitamin $\mathrm{D}$ plays in disease activity. Using the specified MeSH search terms (vitamin D and childhood arthritis), 386 reports (full-text articles, conference abstracts, and letters to the editor) were identified. Thirty-eight studies met the inclusion criteria and are the subject of this review (Table 2). One meta-analysis reported cumulative $25(\mathrm{OH}) \mathrm{D}$ concentrations from fourteen studies comprising children with JIA, JCA, and JRA and other rheumatic conditions; this meta-analysis was not included in our scoping review but is referenced in the discussion [12]. This present review summarizes accumulated evidence on vitamin $\mathrm{D}$ and chronic childhood arthritis by disease activity and latitude. Additionally, this study provides new information about differences in 25(OH)D status between healthy controls and children with JIA.

\section{Vitamin D status in relation to chronic childhood arthritis classification}

Twenty-one of the 38 studies (55.3\%) reported 25(OH)D status for patients with JIA [21-40], eight (21.1\%) for patients with JRA [41-48] and five (13.2\%) for JCA patients [49-53]. Additionally, there were four studies that included patients with juvenile arthritis and other rheumatic diseases [54-57]. As the JRA classification system tended to be applied in North America and the JCA classification in Europe, there was a corresponding hemispheric-specific division in the geographic region from which JRA and JCA articles originated. Studies originated from 17 countries at latitudes ranging from $3^{\circ} \mathrm{S}$ to $61^{\circ} \mathrm{N}$ (Table 2). There were no eligible studies found that reported data below a latitude of $39^{\circ} \mathrm{N}$ prior to the 


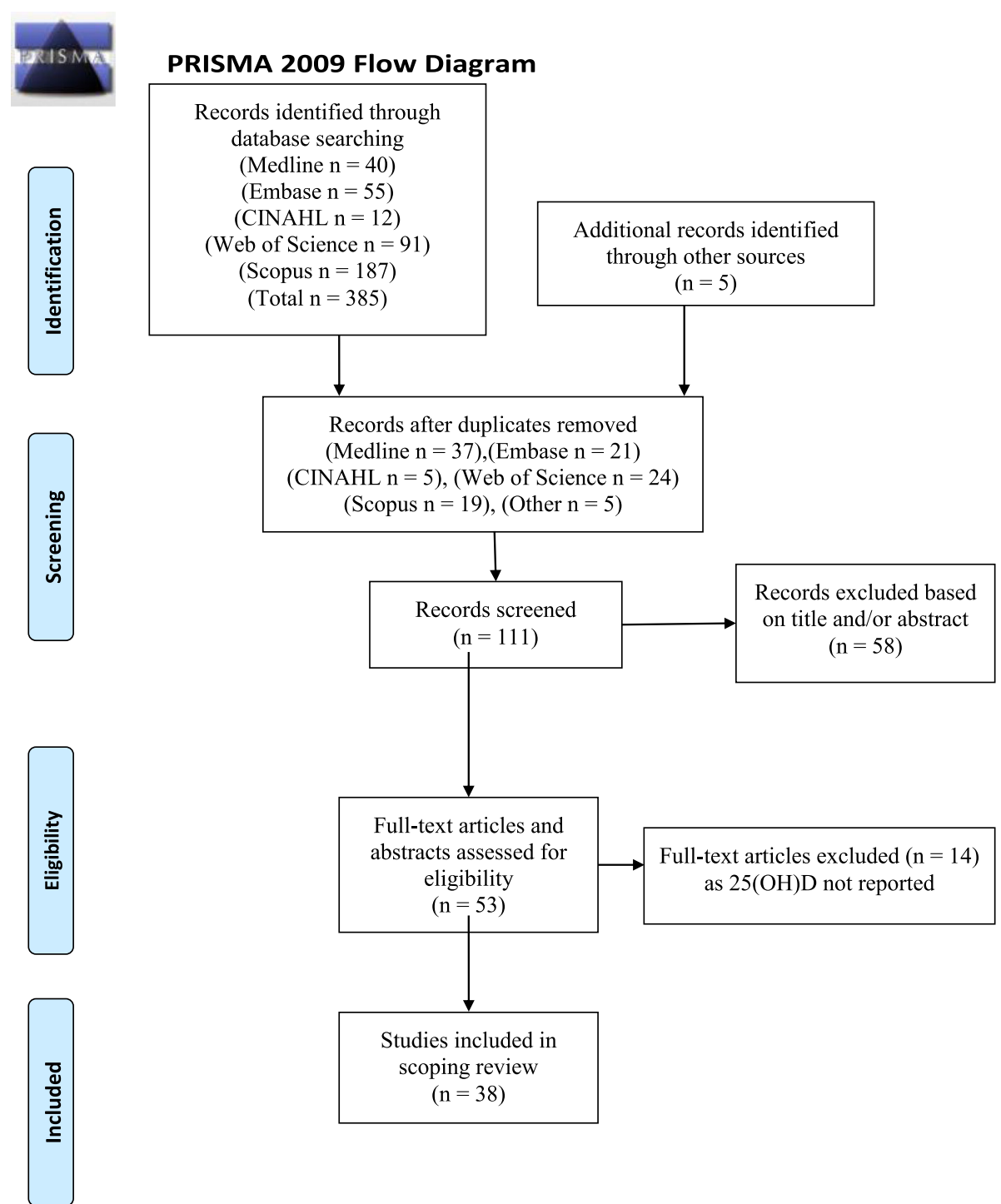

Fig. 1 Articles identified from the retrieved publications reference lists are identified as "other" in the flow diagram

introduction of the ILAR JIA disease classification systemic and no eligible JRA studies above $42^{\circ} \mathrm{N}$.

The 2013, systematic literature review of 19 childhood arthritis studies reported vitamin D status (14 reporting $25(\mathrm{OH}) \mathrm{D}$ and 11 reporting 1,25(OH)D) suggested that at that time there was no clear link between vitamin D status and children with chronic arthritis [12]. The review also contained a meta-analysis comprising three studies that reported the prevalence of vitamin D insufficiency to be $82 \%$ in JIA [12]. Only three studies reported in the meta-analysis were conducted using ILAR JIA criteria [12].

\section{Comparison of study design}

Seventeen studies used a cross-sectional design $(n=17$; $44.7 \%$ ) [27-30, 32-35, 37, 42, 44, 51, 53, 57-59], 16 (42.1\%) a case-control design [21-26, 31, 39, 41, 43, 47-
$50,60]$ and the remainder $(5 ; 13.2 \%)$ were randomized controlled trials $[40,45,46,54,55]$. The primary objective of the majority of studies was to investigate the relationship between juvenile arthritis and bone health $(n=20 ; 52.6 \%)$. In all studies where sex distribution was reported, there were significantly more female participants than males, an observation consistent with the overall preponderance of females in JIA [61]. With the exception of one study [35], the age range of the participants was 0-21 years.

\section{5(OH)D status}

Of the 38 studies reviewed, six (15.8\%) had mean $25(\mathrm{OH}) \mathrm{D}$ concentrations above $75 \mathrm{nmol} / \mathrm{L}[28,42,44,45$, $53,54]$. Seventeen studies $(44.7 \%)$ had mean $25(\mathrm{OH}) \mathrm{D}$ concentrations between 50 and $75 \mathrm{nmol} / \mathrm{L}$ [22, 23, 25, 27, 


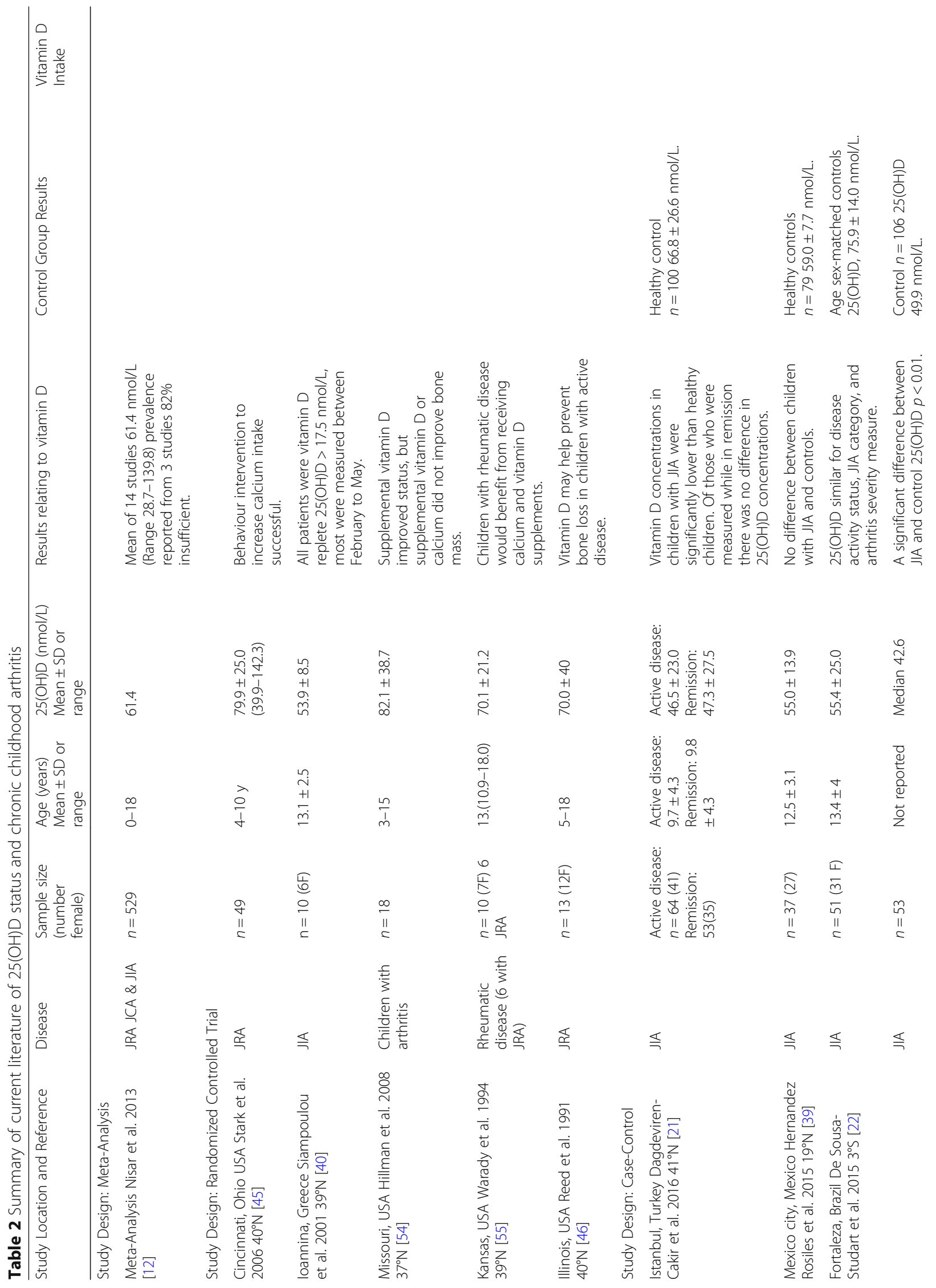




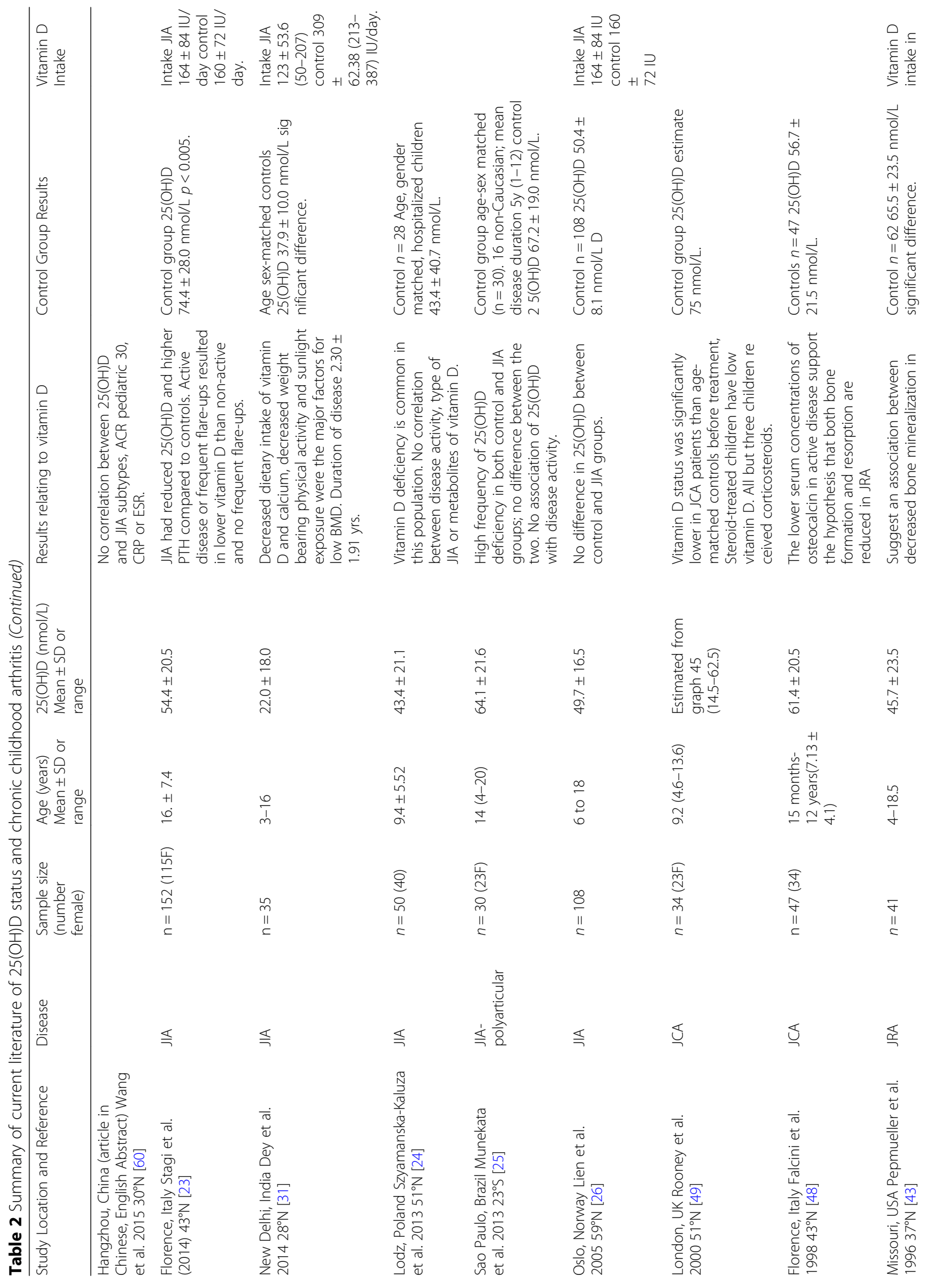




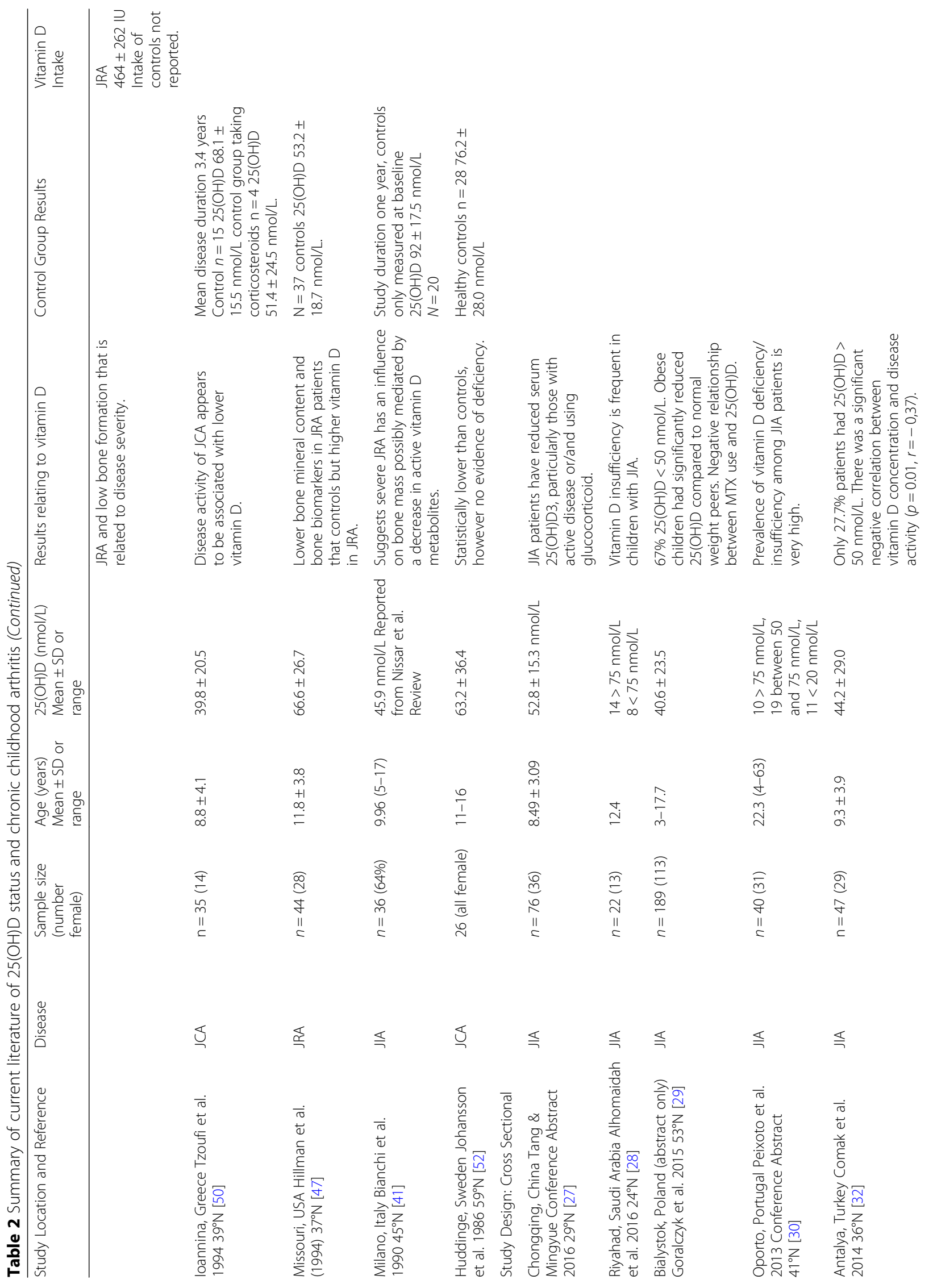




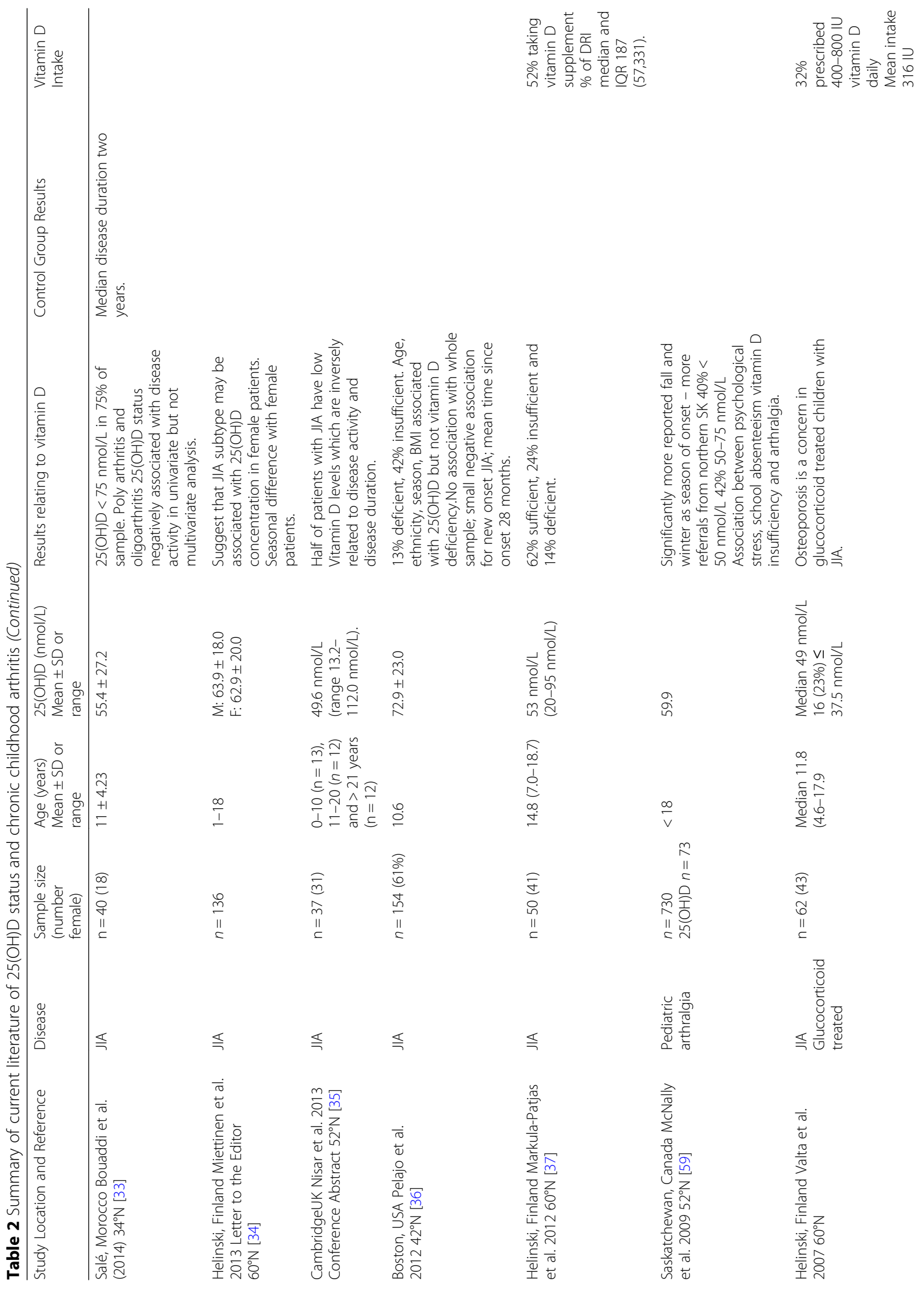


Finch et al. Pediatric Rheumatology (2018) 16:34

Page 9 of 17

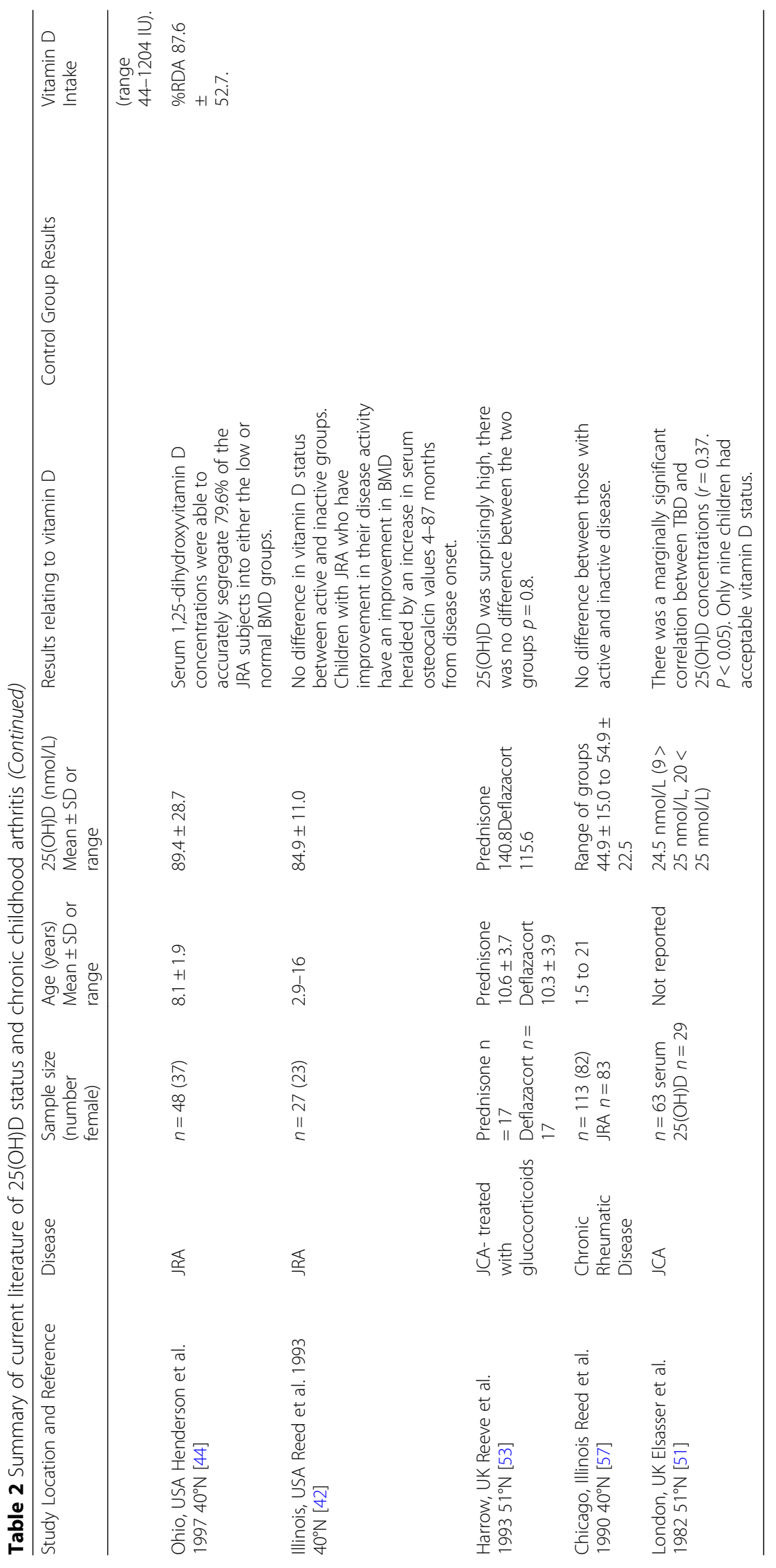


$30,33,34,36,37,39,40,46-48,55,59]$ and $15(39.5 \%)$ had values below $50 \mathrm{nmol} / \mathrm{L}[21,24,26,29,31,32,35,38$, $41,43,49-51,57,60]$. Of those 15 studies, 10 reported the mean $25(\mathrm{OH}) \mathrm{D}$ value, the median value reported for one study and a range or cutoff was provided for four studies). Of the 14 studies $(36.8 \%)$ that published mean $25(\mathrm{OH}) \mathrm{D}$ status of healthy control groups, nine (64.3\%) had mean control values significantly greater than the population with childhood arthritis [21-23, 31, 41, 43, 49, 50], three $(21.4 \%)$ had concentrations that were statistically similar $[25,39,60]$, and two studies $(14.3 \%)$ had mean $25(\mathrm{OH}) \mathrm{D}$ values significantly below the juvenile arthritis comparison groups $[47,48]$. One study compared $25(\mathrm{OH}) \mathrm{D}$ concentrations in children with JIA to hospitalized children and found no statistically significant difference between the two groups [24]. Mean 25(OH)D status of most studies (32 of the 38; 84.2\%) was below the optimal concentration of $75 \mathrm{nmol} / \mathrm{L}$ in children with arthritis [20].

\section{Geography in relation to 25(OH)D status in chronic childhood arthritis}

Vitamin D status in children with JIA appears to follow a north-south gradient (Fig. 2). While this could be due to the diagnostic resources of the countries reporting values, the gradient does appear to be present in Europe where access to care and diagnostic resources are similar. Interestingly, the relationship between reduced vitamin D status and increased disease activity also appears to be present and follow a north-south gradient (Fig. 3). More studies are required to confirm this relationship worldwide, especially in locations around the equator as well as in the southern hemisphere where thus far only two studies have taken place [22, 25].

The major source of vitamin D for most people is endogenous vitamin $\mathrm{D}$ synthesis induced by sunlight exposure [62]. Above $33^{\circ}$ latitude UVB radiation is not intense enough for the cutaneous synthesis of vitamin D all year long [63, 64]. At latitudes $42^{\circ}$ and $53^{\circ}$ North, between October to April, UVB radiation is not intense enough to elicit endogenous vitamin D synthesis [65] thus potentiating the risk of vitamin D deficiency, [63].

The prevalence of JIA, as well as the dominating subtype, varies with latitude [1]. As illustrated in Fig. 2, seven reviewed studies (18.4\%) were conducted in populations residing at latitudes at or below $33^{\circ}[22,25,27$, $28,31,39,60], 19$ studies (50.0\%) were conducted between 33 and $50^{\circ}[21,23,30,32,36,40-48,50,54,55$, $57,66]$, and 12 at a latitude above $50^{\circ}[24,26,29,34,35$, $37,38,49,51,53,59]$. For those below $33^{\circ}, 1$ study (14.3\%) reported a mean $25(\mathrm{OH}) \mathrm{D}$ concentration > $75 \mathrm{nmol} / \mathrm{L}, 4$ (57\%) reported a concentration between 50 and $75 \mathrm{nmol} / \mathrm{L}$, and two (29\%) reported values less than $50 \mathrm{nmol} / \mathrm{L}$. For the studies that took place between 33 and $45^{\circ}$ latitude, four studies (21.1\%) reported a $25(\mathrm{OH}) \mathrm{D}$ concentration $>75 \mathrm{nmol} / \mathrm{L}(21 \%)$, nine $(47.4 \%)$ reported a concentration between 50 and $75 \mathrm{nmol} / \mathrm{L}(47 \%)$ and six (31.6\%) reported values less than $50 \mathrm{nmol} / \mathrm{L}$. From the studies that took place above $45^{\circ}$ latitude, one study (8.3\%) reported a 25(OH)D concentration $>75 \mathrm{nmol} / \mathrm{L}$, four (21.1\%) reported a concentration between 50 and $75 \mathrm{nmol} / \mathrm{L}(33 \%)$ and seven (36.8\%) reported values less than $50 \mathrm{nmol} / \mathrm{L}(39 \%)$.

\section{Current chronic childhood arthritis diagnostic criteria}

Of the 21 studies that applied the current chronic childhood arthritis criteria used by ILAR to diagnose children with JIA, only one study reported mean $25(\mathrm{OH}) \mathrm{D}$ concentrations above $75 \mathrm{nmol} / \mathrm{L}(15 \%)$ [28]. The majority of the studies $(n=11 ; 52.4 \%)$ reported mean concentrations between 50 and $75(52 \%) \mathrm{nmol} / \mathrm{L}$ [22, 23, 25, 27, 30, 33, $34,36,37,40,67]$, and the remaining studies $(n=9$; 42.9\%) reported a mean concentration below $50 \mathrm{nmol} / \mathrm{L}$ (43\%) $[21,24,26,29,31,32,35,38,60]$. As latitude increased, the percentage of studies that reported mean $25(\mathrm{OH}) \mathrm{D}$ in the $50-75 \mathrm{nmol} / \mathrm{L}$ range decreased.

\section{Vitamin $\mathrm{D}$ and disease activity}

No single measure has been established as an accurate indicator of childhood arthritis disease activity. While C-reactive protein and Erythrocyte Sedimentation Rate are indicators of inflammation, they alone do not fully reflect overall disease activity. In the studies reviewed, a variety of validated composite scores were used to measure function or disease activity, including the Childhood Health Assessment Questionnaire (CHAQ), the Juvenile Arthritis Disease Activity Score - 27 (JADAS-27) and American College of Rheumatology Pediatric 30 Criteria (ARC Peds 30) [68-70].

Fifteen of the 38 studies comprising this present review $(39.5 \%)$ evaluated the relationship between vitamin D and disease activity (Fig. 3). Seven studies (18.4\%) reported that patients with active disease or those with elevated inflammatory biomarkers had lower 25(OH)D concentrations than those patients who were in remission or who had less disease activity $[23,27,30,32,35$, $41,50]$. One study $(26.3 \%)$ showed the opposite relationship; those with active disease had higher vitamin D concentrations than those with inactive disease [34]. Of the seven studies $(18.5 \%)$ that reported no relationship between $25(\mathrm{OH}) \mathrm{D}$ and disease activity [21, 22, 25, 33, $36,42,57$ ] one found a relationship between $25(\mathrm{OH}) \mathrm{D}$ concentrations and disease activity in the univariate but not the multivariate analysis [33]. Except for one study conducted in Turkey [21], all other studies conducted in Europe that explored disease activity reported an inverse association between vitamin $\mathrm{D}$ and disease activity.

Long-term cohort studies can further clarify the relationship between vitamin $\mathrm{D}$ concentration and disease 


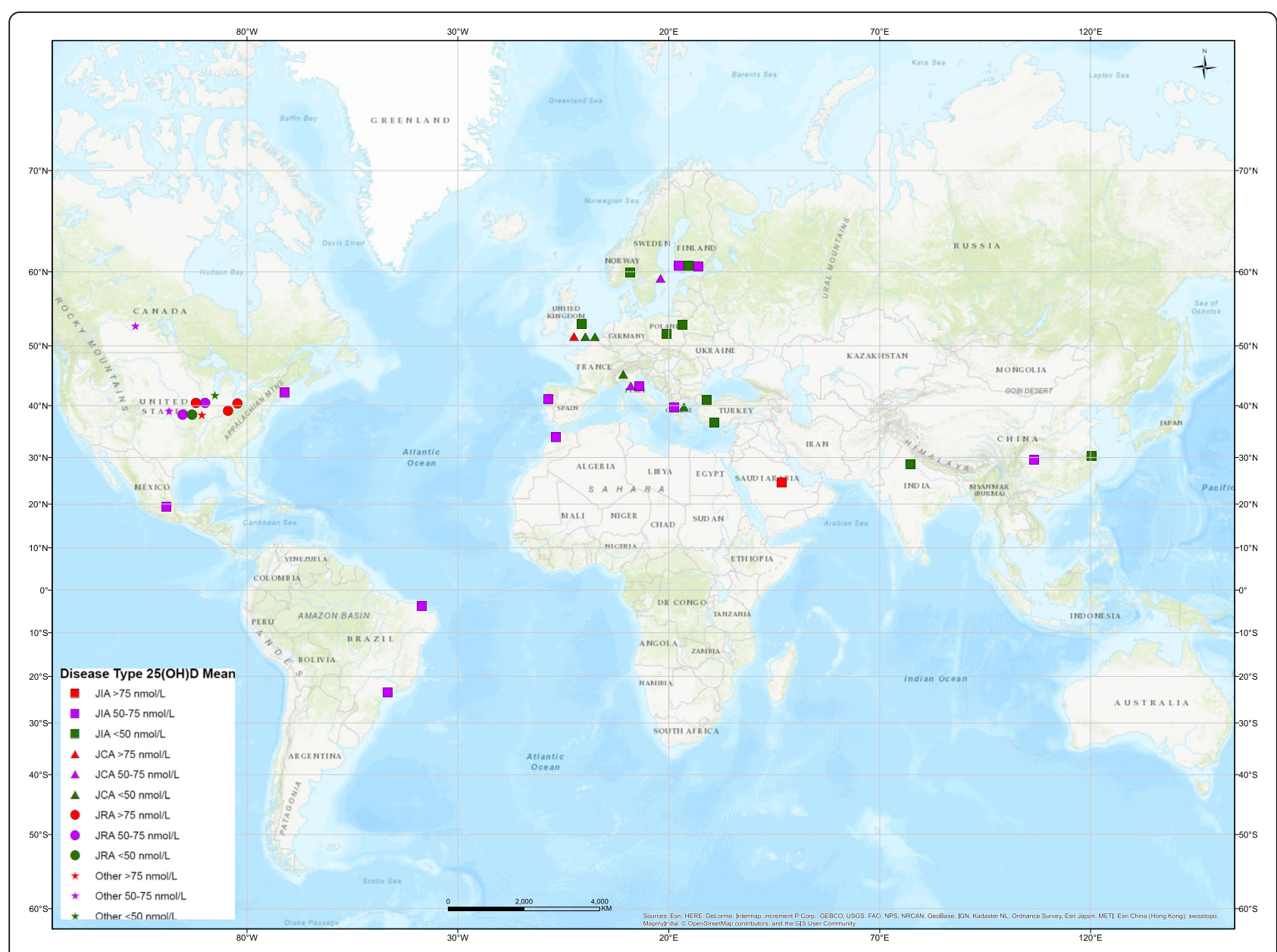

Fig. 2 Disease type by 25(OH)D group. Note: Overlapping points are spread out. Map Produced by The Spatial Initiative, University of Saskatchewan, 2018

duration or frequency of relapse. Such an association was explored in a cross-sectional study which found significantly reduced $25(\mathrm{OH}) \mathrm{D}$ status in JIA patients $(n=152)$ compared with 188 age-and-sex-matched controls [23]. Active disease or frequent relapse was associated with reduced vitamin D status compared to patients with no active disease or frequent flare-ups. The authors questioned whether JIA patients with more severe disease require higher supplementation of vitamin $\mathrm{D}$ to maintain normal $25(\mathrm{OH}) \mathrm{D}$ concentrations. As latitude increases more studies report a difference in vitamin $\mathrm{D}$ status between patients with active versus inactive disease in comparison to lower latitudes as illustrated in Fig. 3.

To date, the evidence to support a relationship between vitamin $\mathrm{D}$ and disease activity with autoimmune diseases in humans is correlative and not causative [71]. Long-term, adequately powered randomized studies which control for confounding variables (sun exposure, season, and vitamin D intake) are required to confirm a causative relationship between vitamin $\mathrm{D}$ and disease activity.

\section{Potential requirements of vitamin $D$ intake}

Vitamin D intake was only measured in seven studies $[23,26,31,37,38,43,44]$. All of these studies reported a mean or median vitamin $D$ intake that was less than the Estimated Average Requirement (EAR) of $400 \mathrm{IU}$ per day set by the IOM [19]. This is the amount of vitamin D that is expected to be sufficient for $50 \%$ of the population [19]. This indicator is used to evaluate the prevalence of inadequacy at the population level. The recommendation at the individual level is the Recommended Dietary Allowance (RDA) which ranges from 400 to $600 \mathrm{IU}$ based on age groups. Two studies reported intake of vitamin $\mathrm{D}$ supplements by study participants but neither had a mean 25(OH)D that reached the optimal concentration [38, 44]. Three studies reported intake of both children with JIA and healthy controls $[23,26,31]$. Vitamin D intake and status was similar for two JIA patient groups [23, 26], and lower intake resulted in lower vitamin D status in the third group [31]. In comparison to the control groups, Lien et al. found similar intake and $25(\mathrm{OH}) \mathrm{D}$ status between those with 


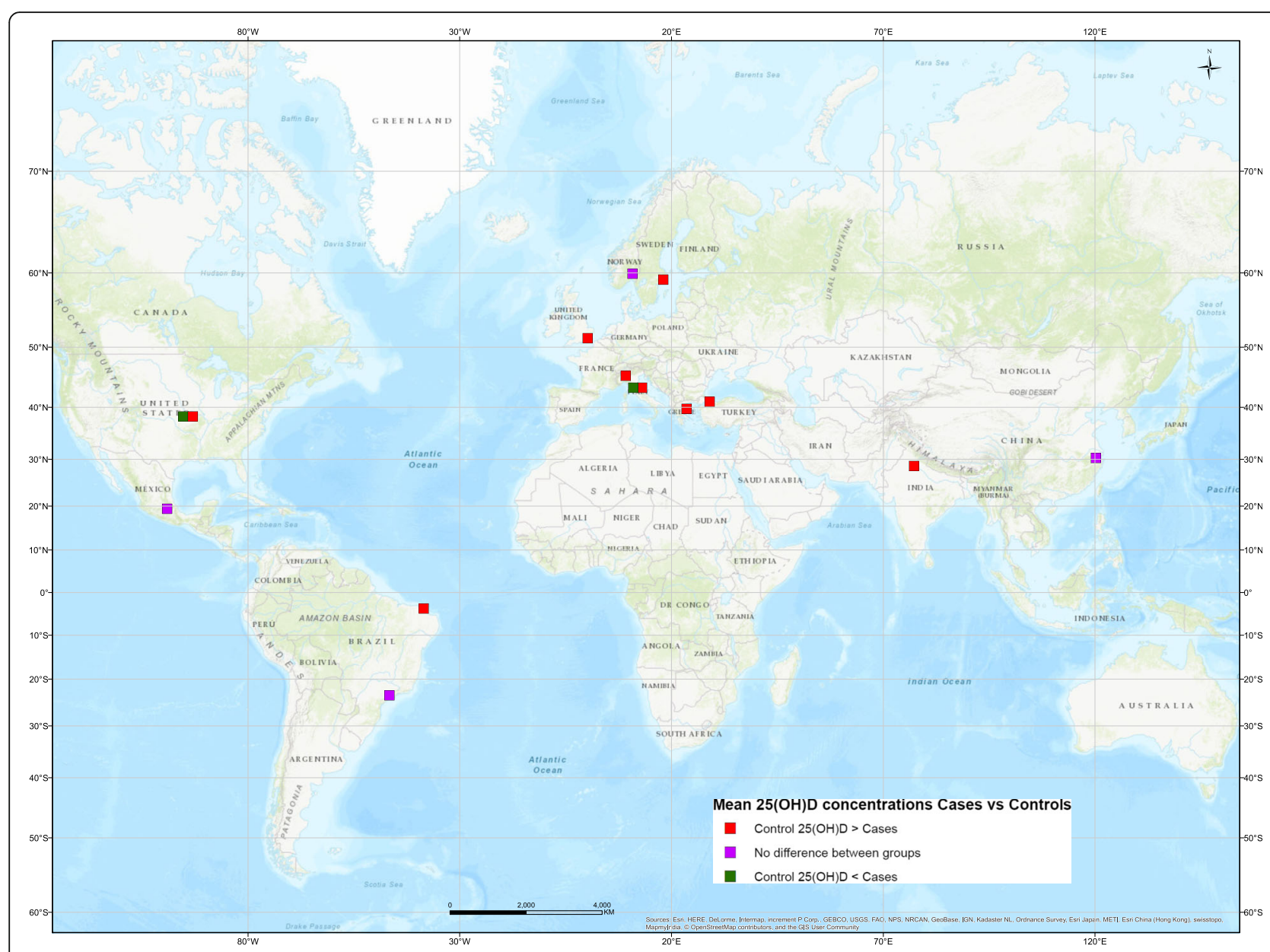

Fig. 3 Difference in $25(\mathrm{OH}) \mathrm{D}$ concentration in active vs inactive chronic childhood arthritis patients. Note: Overlapping points are spread out. Map Produced by The Spatial Initiative, University of Saskatchewan, 2018

JIA and controls [26]. Stagi et al. reported similar intake of vitamin $\mathrm{D}$ and higher $25(\mathrm{OH}) \mathrm{D}$ in controls, and in the study reported by Dey et al. the intake of control participants was two times higher than the participants with JIA and the control group had higher 25(OH)D concentrations [23, 31].

It has been theorized that there may be an increased utilization of vitamin D during active inflammation, possibly caused by 1 the presence of vitamin $\mathrm{D}$ receptor polymorphisms in patients with autoimmune diseases $[6,72]$. Additional studies investigating vitamin D intake from all sources (both food and supplements) are required to determine if children with chronic arthritis require additional vitamin D to maintain serum concentrations in comparison to healthy children. Understanding this relationship will be important in the use of vitamin D as a potential adjunct therapy. Additionally, improved understanding of vitamin D needs in children with chronic arthritis will help to clarify the role of vitamin $\mathrm{D}$ in the underlying disease processes so that therapies that target specific vitamin D responsive immune pathways can be developed. By exploring the factors that influence vitamin D status (genetics, environment, and nutrition), we will be better able to discern an association between vitamin $\mathrm{D}$ and JIA.

Two articles have discussed vitamin $\mathrm{D}$ requirements for children with rheumatic conditions not in the context of corticosteroids. In 2011, von Scheven and Burnham suggested that in the absence of specific guidelines for children with rheumatic conditions that the American Academy of Pediatrics guidelines of 400 IU per day be used as a suggested minimum dosing regimen [4]. The authors cautioned that providing large doses of vitamin D can result in providing "too much of a good thing" and that studies comparing children with rheumatic diseases to healthy children are required. The second article was published by Vojinovic and Cimaz in 2015 and recommends that the guidelines set out by the Endocrinology Society for patients receiving corticosteroids be followed for all children with rheumatic diseases [73]. This would result in a dose of 2-3 times the current recommendation 
and would be approximately $2000 \mathrm{IU} /$ day. This dose is still below the IOM's tolerable upper limit for all children over the age of one (2500 IU) [19].

\section{Vitamin $\mathrm{D}$ and medication interactions in JIA patients}

All but one study [24], have been conducted with children already being treated for arthritis, many receiving corticosteroids, which could impact $25(\mathrm{OH}) \mathrm{D}$ concentration and inflammatory status. Corticosteroids promote the breakdown of both 25(OH)D and 1,25(OH)D and also counteract effects of vitamin $\mathrm{D}$ on bone formation [74, 75]. These patients also had varying disease duration. A study of newly diagnosed individuals, however, did not compare patients with JIA to healthy controls but to hospitalized children [24] . Comparing children with JIA to healthy controls allows for discerning biologic differences that could inform treatment targets.

The lowest mean 25(OH)D concentration, $22 \mathrm{nmol} / \mathrm{L}$ $(n=35)$ was reported from India. These patients were found to be consuming significantly less vitamin D and had less sun exposure compared to healthy controls [31]. The highest 25(OH)D, $140.8 \mathrm{nmol} / \mathrm{L} \quad(n=17)$, concentrations were reported in Finland, in a population receiving Prednisone [53]. The authors hypothesized that the reason their patients' $25(\mathrm{OH}) \mathrm{D}$ concentrations were so high was that their previous research had found low concentrations of $25(\mathrm{OH}) \mathrm{D}$ and they were encouraging their patients to consume vitamin D fortified foods and to spend time in the sun [53]. A survey of steroid-related osteoporosis, prevention and treatment practices of pediatric rheumatologists in North America was conducted by Soybilgic et al. in 2014 [76]. They found that the majority of pediatric rheumatologists are recommending vitamin $\mathrm{D}$ for patients who were on long-term corticosteroids [76]. The role of vitamin D in mediating bone health, especially in relation to corticosteroids, has been established [75]. Both short and long-term corticosteroid intake even at small doses impact bone health in patients with autoimmune diseases [74]. The role and an appropriate amount of vitamin D intake or $25(\mathrm{OH}) \mathrm{D}$ target for inflammation or disease activity have yet to be established.

\section{Additional research directions}

Considering ethnicity when comparing incidence and prevalence amongst populations would be useful in understanding if the regional differences observed are due to environmental or genetic factors or a combination of the two. Evidence from a multiethnic cohort study of 1082 children at The Hospital for Sick Children, Toronto, Canada investigated the influence of ethnicity on the risk of developing JIA [77]. When the diversity of the study population was compared to that of the general Toronto region population, there was an overrepresentation of patients of European and Indigenous descent and an underrepresentation of patients of Black, Asian, or Indian subcontinent ethnicity in their cohort. European descent was significantly associated with an increased risk of developing JIA, including all subtypes except RF-positive polyarticular JIA. Exploring the environmental and genetic factors that may contribute to JIA risk in the same individual will help to clarify these findings.

While this review focused on vitamin D status in children with JIA, vitamin D may be involved in both disease development and subsequent disease activity status. Exploring elements of vitamin D status that may have a role in disease development such as early life and gestational vitamin $\mathrm{D}$ status as well as genes in the vitamin $\mathrm{D}$ pathway will help to clarify the role of vitamin D.

Season of birth has been suggested to have an impact on the risk of developing a number of autoimmune diseases such as multiple sclerosis, type 1 diabetes and celiac disease [78]. A recent study investigating month of birth and risk of JIA found a difference in the pattern of the birth month for children with JIA compared to that of the general population [78]. Children with JIA were more likely to be born between November to March, with the birth month for the general population peaking in the summer months. The study by Carlens et al. also investigated the relationship between season of birth and the risk of developing JIA and found no increased risk [79]. Season of birth may be a marker for vitamin $\mathrm{D}$ status in utero with children born in the non-vitamin D synthesizing periods being exposed to less vitamin $\mathrm{D}$ during their time in utero than those who are born during the vitamin D synthesizing seasons.

The Childhood Arthritis Risk factor Identification sTudY (CLARITY) explored the use of nutritional supplements during pregnancy and the risk of developing JIA [80]. The use of vitamin D and fish oil during pregnancy in case mothers was not significantly different from controls following covariate adjustments [80]. A case-cohort investigation from Denmark, comparing $25(\mathrm{OH}) \mathrm{D}$ status in children diagnosed with either oligoarticular or polyarticular JIA using dried blood spot samples that were collected at birth did not find any association between $25(\mathrm{OH}) \mathrm{D}$ status at birth and risk of developing JIA [81]. Concentrations of 25(OH)D fluctuated significantly by season of birth and year of birth (calendar year). There was no follow up to determine if $25(\mathrm{OH}) \mathrm{D}$ status or season during the first few months of life impacted risk of JIA or whether other subtypes of JIA were impacted by season of birth of $25(\mathrm{OH}) \mathrm{D}$ status at birth.

Certain VDR gene polymorphisms may be associated with different biologic response to vitamin $\mathrm{D}$. The $\mathrm{Cdx} 2$ polymorphism of the VDR gene specifically the GG genotype, have been suggested to be more represented 
in patients with JIA compared to healthy controls who more often have the GA genotype [82]. Recently the idea of investigating epistasis (gene-gene interactions) amongst genes in the inflammatory and vitamin $\mathrm{D}$ pathway and how their interactions contribute to JIA risk was explored by Ellis et al. [86]. This is the first study to explore this interaction, and the authors suspect that through exploring these interactions there is the opportunity to account for the missing heritability that has been observed with complex diseases with genetic components [86]. Their work found evidence of epistasis amongst tyrosine-protein phosphatase non-receptor type 2 (PTPN2) gene and the vitamin $\mathrm{D}$ binding protein gene in contributing to the risk of JIA [86]. The role of genes in the vitamin D pathway on both disease development and disease activity are still in the early stages of investigation. Also how they impact the biological response involving vitamin $\mathrm{D}$ and inflammation remains unclear. Investigating genetic, nutritional and environmental factors that influence vitamin D in JIA could help inform ways in which vitamin D status influences the occurrence and activity of JIA. Understanding if genetic variants increase the risk of disease development will help tailor vitamin D management in individual patients and contribute to improving control of disease activity and improve outcomes.

A north-south gradient of incidence and a mechanism for the suppression of inflammation in relation to $25(\mathrm{OH}) \mathrm{D}$ status has been suggested. However, no study has summarized the current evidence of chronic childhood arthritis diagnosis by $25(\mathrm{OH}) \mathrm{D}$ status in relation to latitude and disease activity. This first step is important for the development of future studies leading to the exploration of potential optimal target concentrations of vitamin $\mathrm{D}$ for the reduction of inflammation in children with chronic arthritis.

\section{Limitations}

This scoping review has limitations due to the limited amount of comparative data. Season of measurement and JIA subtype could not be considered due to a lack of reporting in most reviewed articles. With the exception of one study, all studies reviewed used various unreported types of medication in patients who had had JIA for varying durations. These variables can make it difficult to interpret the relationship between vitamin D and disease activity in relation to both inflammation status and risk of relapse. Of the studies that investigated the relationship between vitamin $\mathrm{D}$ and function or disease activity, various measures were used. The most common included the CHAQ, JADAS-27 and ARC Peds 30. The JADAS-27 and ACRS Peds 30 both include active joint counts in their scoring which confounds comparisons of disease activity between patients with different JIA that are defined by numbers of joints involved. Subtypes [17,
83, 84]. Many studies included multiple subtypes of JIA measured by the same disease activity score that included an active joint count. This review was unable to explore the relationship between vitamin $\mathrm{D}$ status and ethnicity, vitamin $\mathrm{D}$ receptor genes or other genes that influence vitamin D metabolism.

\section{Conclusion}

This is the first scoping review to summarize research relating to vitamin D and JIA in the context of vitamin D status, latitude, disease activity. It is also the first to map the results according to geography. Thirty-two studies $(84.2 \%)$ reported a mean $25(\mathrm{OH}) \mathrm{D}$ concentration below $75 \mathrm{nmol} / \mathrm{L}$ or the optimal value. This suggests that whether due to inadequate intake or increased utilization the majority of children with juvenile arthritis do not have optimal 25(OH)D status as defined by the Endocrine Society [20]. The optimal concentration of $25(\mathrm{OH}) \mathrm{D}$ and the corresponding dietary requirements for patients with chronic childhood arthritis has yet to be determined. Further, the relationship between vitamin D status and disease activity in children with JIA is still unclear. Studying newly diagnosed patients who are treatment naive for longer periods of time would help characterize this relationship as there would be fewer confounders associated with patients who have had the disease for varying durations (medication, lifestyle modifications, and disease duration). Thus far, we know that there is a role for vitamin $\mathrm{D}$ in the inflammatory pathways, a high prevalence of $25(\mathrm{OH}) \mathrm{D}$ insufficiency among children with JIA, and an established link of vitamin D with other autoimmune diseases. We do not, however, know the optimal vitamin D status for children with JIA, whether reduced vitamin $\mathrm{D}$ is caused by increased utilization or reduced vitamin D status in children with JIA, the impact of vitamin D in disease activity or the role of VDR polymorphisms with JIA. Larger, long-term studies of new-onset JIA are required to explore the association. The relationship between vitamin D status and JIA over time in newly diagnosed individuals has yet to be investigated. Investigating the genetic and environmental role that vitamin $\mathrm{D}$ plays in the prevention and control of JIA in the same children will help to tease out the multifaceted role played by vitamin $\mathrm{D}$ in this disease. Being able to suggest specific targets for vitamin D status as a potential adjunct therapy in the treatment of JIA and understanding how genetic variants increase the risk of disease development will enhance the quality of life of patients and their families.

\section{Abbreviations}

1,25(OH)2D): 1,25-dihydroxyvitamin D; 25(OH)D: 25-dihydroxyvitamin D;

CINHAL: Cumulative Index to Nursing and Allied Health Literature;

CLARITY: Childhood Arthritis Risk factor Identification sTudY;

CYP27B1: Cytochrome p450 27B1; GIS: Geographic Information Systems; 
IOM: Institute of Medicine; JCA: Juvenile Chronic Arthritis; JIA: Juvenile Idiopathic Arthritis; JRA: Juvenile Rheumatoid Arthritis; MeSH: Medical Subject Heading; VDR: Vitamin D receptor

\section{Acknowledgments}

We acknowledge the help of Vicky Duncan, Librarian, University of Saskatchewan, in designing the outline of the search procedure, and Dr. Weiping Zeng of the Spatial Analysis Initiative/Social Science Research Laboratory at the University of Saskatchewan for creating maps. This research was supported, in part, by the Jim Pattison Children's Hospital Foundation of Saskatchewan.

\section{Funding}

The University of Saskatchewan Scholarship for Sarah Finch.

The Jim Pattison Children's Hospital Foundation.

\section{Authors' contributions}

The co-authors designed the review. SF drafted the manuscript under the direct supervision of HV and AR. HV and AR provided critical review and feedback throughout different stages of the manuscript preparation. All authors read and approved the final manuscript.

\section{Ethics approval and consent to participate}

This paper is a review article, does not need ethic approval.

\section{Competing interests}

The authors declare that they have no competing interests.

\section{Publisher's Note}

Springer Nature remains neutral with regard to jurisdictional claims in published maps and institutional affiliations.

\section{Author details}

${ }^{1}$ College of Pharmacy and Nutrition, University of Saskatchewan, Saskatoon, Canada. ${ }^{2}$ Department of Pediatrics, University of Saskatchewan, Saskatoon, Canada. ${ }^{3}$ College of Pharmacy \& Nutrition and School of Public Health, University of Saskatchewan, 104 Clinic Place, Saskatoon, SK S7N 2Z4, Canada.

\section{Received: 31 December 2017 Accepted: 7 May 2018}

\section{Published online: 16 May 2018}

\section{References}

1. Manners PJ, Bower C. Worldwide prevalence of juvenile arthritis - why does it vary so much? J Rheumatol. 2002:29:1520-30.

2. Brewer EJ Jr, Bass J, Baum J, Cassidy JT, Fink C, Jacobs J, Hanson V, Levinson JE, Schaller JSJ. Current proposed revision of JRA criteria. JRA criteria Subcommittee of the Diagnostic and Therapeutic Criteria Committee of the American rheumatism section of the Arthritis Foundation. Arthritis Rheum. 1977:20:195-9.

3. Woods P. Special meeting on nomenclature and classification of arthritis in children. Basel: EULAR Publishers; 1978. p. 47-50.

4. Von Scheven E, Burnham JM. Vitamin D supplementation in the pediatric rheumatology clinic. Curr Rheumatol Rep. 2011;13:110-6.

5. Agmon-Levin N, Theodor E, Segal RM, Shoenfeld Y. Vitamin D in systemic and organ-specific autoimmune diseases. Clin Rev Allergy Immunol. 2013; 45:256-66

6. Cutolo M, Pizzorni C, Sulli A. Vitamin D endocrine system involvement in autoimmune rheumatic diseases. Autoimmun Rev. 2011;11:84-7.

7. Hewison M. Vitamin $D$ and the immune system: new perspectives on an old theme. Rheum Dis Clin N Am. 2012;38:125-39.

8. Adorini L, Penna G. Control of autoimmune diseases by the vitamin D endocrine system. Nat Clin Pract Rheumatol. 2008;4:404-12.

9. Holick MF. Vitamin D: Extraskeletal Health. Rheum Dis Clin N Am. 2012; 38:141-60.

10. Baeke F, Takiishi T, Korf H, Gysemans C, Mathieu C. Vitamin D: modulator of the immune system. Curr Opin Pharmacol. 2010;10:482-96.

11. Sabbagh Z, Markland J, Vatanparast H. Vitamin D status is associated with disease activity among rheumatology outpatients. Nutrients. 2013; 5:2268-75.

12. Nisar MK, Masood F, Cookson P, Sansome A, Ostör AJK. What do we know about juvenile idiopathic arthritis and vitamin D? A systematic literature review and meta-analysis of current evidence. Clin Rheumatol. 2013:32:729-34

13. Daudt HM, van Mossel C, Scott SJ. Enhancing the scoping study methodology: a large, inter-professional team's experience with Arksey and O'Malley's framework. BMC Med Res Methodol. 2013;13:48.

14. Arksey H, Malley LO. Scoping studies: towards a methodological framework. Int J Soc Res Methodol. 2005;8:19-32.

15. Levac D, Colquhoun H, O'Brien KK. Scoping studies: advancing the methodology. Implement Sci. 2010;5:69.

16. Colquhoun HL, Levac D, O'Brien KK, Straus S, Tricco AC, Perrier L, et al. Scoping reviews: time for clarity in definition, methods, and reporting. J Clin Epidemiol. 2014;67:1291-4

17. Petty R, Southwood T, Manners P. International league of associations for rheumatology. International league of associations for rheumatology classification of juvenile idiopathic arthritis. J Rheumatol. 2004:31:390-2.

18. Moher D, Liberati A, Tetzlaff J, Altman DG. Systematic reviews and metaanalyses: the PRISMA statement. Annu Intern Med. 2009:151:264-9.

19. Institute of Medicine. Food and nutrition board, dietary reference intakes for calcium and vitamin D. Washington: National Academy Press; 2010.

20. Holick MF, Binkley NC, Bischoff-Ferrari HA, Gordon CM, Hanley DA, Heaney RP, et al. Evaluation, treatment, and prevention of vitamin D deficiency: an Endocrine Society clinical practice guideline. J Clin Endocrinol Metab. 2011; 96:1911-30.

21. Dağdeviren-çakır A, Arvas A, Barut K, Gür E, Kasapçopur Ö. Serum vitamin D levels during activation and remission periods of patients with juvenile idiopathic arthritis and familial Mediterranean fever. Turk J Pediatr. 2016;58: 125-31.

22. de Sousa Studart SA, Leite AC, Marinho AL, Pinto AC, Rabelo Júnior CN, de Melo NR, et al. Vitamin D levels in juvenile idiopathic arthritis from an equatorial region. Rheumatol Int. 2015:35:17-23.

23. Stagi S, Bertini F, Cavalli L, Matucci-cerinic M, Brandi ML, Falcini F. Determinants of vitamin D levels in children, adolescents, and young adults with juvenile idiopathic arthritis determinants of vitamin D levels in children, adolescents, and young adults with juvenile idiopathic arthritis. J Rheumatol. 2014:41:1884-92

24. Szymańska-Kałuża J, Biernacka-ZielińskaM, Stańczyk J, Smolewska E. Vitamin $\mathrm{D}$ level in children with juvenile idiopathic arthritis and its correlation with clinical picture of the disease. Reumatologia. 2013:51:271-6.

25. Munekata RV, Terreri MTRA, Peracchi OAB, Len C. Serum 25-hydroxyvitamin $\mathrm{D}$ and biochemical markers of bone metabolism in patients with juvenile idiopathic arthritis. Braz J Med Biol Res. 2013;46:98-102.

26. Lien G, Selvaag AM, Flatø B, Haugen M, Vinje O, Sørskaar D, et al. A two-year prospective controlled study of bone mass and bone turnover in children with early juvenile idiopathic arthritis. Arthritis Rheum. 2005;52:833-40.

27. Tang X. Mingyue L. Association between vitamin D concentrations with disease activity and bone mineral density of juvenile idiopathic arthritis patients. International Journal of Rheumatic Diseases. Conference: 18th Asia Pacific League of Associations for Rheumatology Congress, APLAR. China. 2016. Conference Start 20160926 . Conference End: 20160929 . 2016:19:158.

28. Alhomaidah D, Alsagheir A, Al-mayouf SM. ScienceDirect coexistence of endocrinopathies in children with rheumatic diseases. Int J Pediatr Adolesc Med. 2016;3:119-22.

29. Goralczyk A, Konstantynowicz J, Abramowicz P, Dobrenko E, Babinska-Malec E. Deficits of vitamin D are strongly associated with methotrexate treatment in patients with juvenile idiopathic arthritis. Bone Abstr. 2015:183

30. Peixoto D, Teixeira F, Lucas R, Costa J, Costa L, AD. Vitamin D status in patients with juvenile idiopathic arthritis. Ann. Rheum. Dis. Conf. Annu. Eur. Congr. Rheumatol. Eur. Leag. Against Rheum. EULAR. 2012;2013:71.

31. Dey S, Jahan A, Yadav TP, Bhagwani DK, Sachdev N. Measurement of bone mineral density by dual energy $X$-ray absorptiometry in juvenile idiopathic arthritis. Indian J Pediatr. 2014;81:126-32.

32. Çomak E, Doğan ÇS, Uslu-gökçeoğlu A, Akbaş H, Özdem S. Association between vitamin $D$ deficiency and disease activity in juvenile idiopathic arthritis. Turk J Pediatr. 2014:56:626-31.

33. Bouaddi I, Rostom S, El Badri D, Hassani A, Chkirate B, Abouqal R, et al. Vitamin D concentrations and disease activity in Moroccan children with juvenile idiopathic arthritis. BMC Musculoskelet Disord. 2014;15:115.

34. Miettinen ME, Kinnunen L, Harjutsalo V, Reinert-Hartwall L, LambergAllardt C, Toumilehto J, Saila H. Serum 25-hydroxyvitamin D in juvenile idiopathic arthritis patients in Finland-letters to the editors. Clin Exp Rheumatol. 2013;31:988 
35. Nisar M, Cookson P, Masood F, Sansome A, Ostor A. Is there a link between vitamin D and juvenile idiopathic arthritis? Ann Rheum Dis Conf Annu Eur Congr Rheumatol Eur Leag Against Rheum EULAR. Conference Start: 20130612. Conference End:20130615.2013:72.

36. Pelajo CF, Lopez-Benitez JM, Kent DM, Price LL, Miller LC, Dawson-Hughes B. 25-hydroxyvitamin D levels and juvenile idiopathic arthritis: is there an association with disease activity? Rheumatol Int. 2012;32:3923-9.

37. Markula-patjas KP, Valta HL, Kerttula LI, Soini IH, Honkanen VEA, Mäkitie OM, et al. Prevalence of vertebral compression fractures and associated factors in children and adolescents with severe juvenile idiopathic arthritis prevalence of vertebral compression fractures and associated factors in children and adolescents with severe Juvenil. J Rheumatol. 2012;39:365-73.

38. Valta $H$, Lahdenne $P$, Jalanko $H$, Aalto K. Bone health and growth in glucocorticoid-treated patients with juvenile idiopathic arthritis. J Rheumatol. 2007;34:831-6.

39. Rosiles VH, Salazar CD, Velazquez RM, Ruiz RR, CP. Determination of $25(\mathrm{OH}) \mathrm{D}$ serum levels in children with systemic lupus erythematosus and juvenile idiopathic arthritis. Bol Med del Hosp Infant Mex. 2015;72:99-105.

40. Siamopoulou A, Challa A, Kapoglou P, Cholevas V, Mavridis AK, Lapatsanis PD. Effects of intranasal salmon calcitonin in juvenile idiopathic arthritis: an observational study. Calcif Tissue Int. 2001;69:25-30.

41. Bianchi ML, Bardare M, Caraceni MP, Cohen E, Falvella S, Borzani M, et al. Bone metabolism in juvenile rheumatoid arthritis. Bone Miner. 1990;9:153-62.

42. Reed AM, Haugen M, Pachman LM, Langman CB. Repair of osteopenia in children with juvenile rheumatoid arthritis. J Pediatr. 1993;122:693-6.

43. Pepmueller PH, Cassidy JT, Allen SH, Hillman LS. Bone mineralization and bone mineral metabolism in children with juvenile rheumatoid arthritis. Arthritis Rheum. 1996:39:746-57.

44. Henderson CJ, Cawkwell GD, Specker BL, Sierra RI, Wilmott RW, Campaigne $\mathrm{BN}$, et al. Non-corticosteroid-treated prepubertal children with juvenile rheumatoid arthritis. Arthritis Rheum. 1997;40:1967-75.

45. Stark $\sqcup$, Davis AM, Janicke DM, Mackner LM, Hommel KA, Bean JA, Lovell D, Heubi JE, KH. A randomized clinical trial of dietary calcium to improve bone accretion in children with juvenile rheumatiod arthritis. Pediatrics. 2006;148:501-7.

46. Reed A, Haugen M, Pachman LM, Langman CB. 25-Hydroxyvitamin D therapy in children with active juvenile rheumatoid arthritis: short-term effects on serum osteocalcin levels and bone mineral density. J Pediatr. 1991;119:657-60.

47. Hillman L, Cassidy JT, Johnson L, Lee D, Allen SH. Vitamin D metabolism and bone mineralization in children with juvenile rheumatoid arthritis. J Pediatr. 1994;124:910-6.

48. Falcini F, Ermini M, Bagnoli F. Bone turnover is reduced in children with juvenile rheumatoid arthritis. J Endocrinol Investig. 1998;21:31-6.

49. Rooney M, Davies UM, Reeve J, Preece M, Ansell BM, WP. Bone mineral content and bone mineral metabolism: changes after growth hormone treatment in juvenile chronic arthritis. J Rheumatol. 2000;27:1073-81.

50. Tzoufi M, Siamopoulou-Mavridou A, Challa A, Lapatsanis PD. Changes of mineral metabolism in juvenile chronic arthritis. Acta Paediatr Suppl. 1994; 394:52-7.

51. Elsasser U, Wilkins B, Hesp R, Thurnham DI, Reeve J, Ansell BM. Bone rarefaction and crush fractures in juvenile chronic arthritis. Arch Dis Child. 1982:57:377-80

52. Johansson U, Portinsson S, Akesson A, Svantesson H, Ockerman PA, Akesson B. Nutritional status in girls with juvenile arthritis. Hum Nutr - Clin Nutr. 1986:41:57-67.

53. Reeve J, Loftus J, Hesp R, Ansell BM, Wright DJ, Woo PMM. Biochemical prediction of changes in spinal bone mass in juvenile chronic (or rheumatoid) arthritis treated with glucocorticoids. J Rheumatol. 1993;20:1189-95.

54. Hillman LS, Cassidy JT, Chanetsa F, Hewett JE, Higgins BJ, Robertson JD. Percent true calcium absorption, mineral metabolism, and bone mass in children with arthritis: effect of supplementation with vitamin D3 and calcium. Arthritis Rheum. 2008:58:3255-63.

55. Warady BD, Lindsley CB, Robinson FG, LB. Effects of nutritional supplementation on bone mineral status of children with rheumatic diseases receiving corticosteroid therapy. J Rheumatol. 1994;21:530-5.

56. McNally JD, Menon K, Chakraborty P, Fisher L, Williams KA, Al-Dirbashi OY, et al. The Association of Vitamin D Status with Pediatric Critical IIness. Pediatrics. 2012;130:429-36.

57. Reed A, Haugen M, Pachman LM, Langman CB. Abnormalities in serum osteocalcin values in children with chronic rheumatic diseases. J Pediatr. 1990;116:574-80.
58. Pelajo CF, Lopez-Benitez JM, Miller LC. Obesity and disease activity in juvenile idiopathic arthritis. Pediatr Rheumatol. 2012;10:3.

59. McNally JD, Matheson LA, Rosenberg AM. Epidemiologic considerations in unexplained pediatric arthralgia: the role of season, school, and stress. J Rheumatol. 2009;36:427-33.

60. Wang Y, Lu MP, Teng LP, Guo L, Xu YP, Zou LX, et al. Association of vitamin D concentrations with juvenile idiopathic arthritis. Zhongguo Dang Dai Er Ke Za Zhi. 2015;17:375-8.

61. Borchers AT, Selmi C, Cheema G, Keen CL, Shoenfeld Y, Gershwin ME. Juvenile idiopathic arthritis. Autoimmun Rev. 2006;5:279-98.

62. Holick MF. Biological effects of sunlight, ultraviolet radiation, visible light, infrared radiation and vitamin D for health. Anticancer Res. 2016;36:1345-56.

63. Tsiaras WG, Weinstock MA. Factors influencing vitamin d status. Acta Derm Venereol. 2011;91:115-24.

64. Wacker M, Holick MF. Sunlight and vitamin D: a global perspective for health. Dermatoendocrinol. 2013;5:51-108.

65. Webb AR, Kline L, Holick MF. Influence of season and latitude on the cutaneous synthesis of vitamin D3: exposure to winter sunlight in Boston and Edmonton will not promote vitamin D3 synthesis in human skin. J Clin Endocrinol Metab. 1988;67:373-8.

66. Rosiles VH, Salazar CD, Velazquez RM, Ruiz RR, Clark P. Determination of 25(OH)D serum levels in children with systemic lupus erythematosus and juvenile idiopathic arthritis. Bol Med Hosp Infant Mex. 2015;72:99-105.

67. Duffy CM. Measurement of health status, functional status, and quality of life in children with juvenile idiopathic arthritis: clinical science for the pediatrician. Rheum Dis Clin N Am. 2007;33:389-402.

68. Ringold S, Wallace CA. Measuring clinical response and remission in juvenile idiopathic arthritis. Curr Opin Rheumatol. 2007;19:471-6.

69. Ringold S, Weiss PF, Beukelman T, Dewitt EM, llowite NT, Kimura Y, et al. 2013 update of the 2011 American College of Rheumatology recommendations for the treatment of juvenile idiopathic arthritis: recommendations for the medical therapy of children with systemic juvenile idiopathic arthritis and tuberculosis screening among c. Arthritis Care Res. 2013;65:1551-63.

70. Dankers W, Colin EM, van Hamburg JP, Lubberts E. Vitamin D in autoimmunity: molecular mechanisms and therapeutic potential. Front Immunol. 2017;7:697.

71. Cutolo M, Otsa K, Uprus M, Paolino S, Seriolo B. Vitamin D in rheumatoid arthritis. Autoimmun Rev. 2007:7:59-64.

72. Vojinovic J, Cimaz R. Vitamin D-update for the pediatric rheumatologists Pediatr Rheumatol Online J. 2015:13:18.

73. Gröber U, Spitz J, Reichrath J, Kisters K, Holick MF. Vitamin D: update 2013 from rickets prophylaxis to general preventive healthcare. Dermatoendocrinol. 2013;5:331-47.

74. Gröber U, Kisters K. Influence of drugs on vitamin D and calcium metabolism. Dermatoendocrinol. 2012:4:158-66.

75. Soybilgic A, Tesher M, Wagner-Weiner L, Onel KB. A survey of steroid-related osteoporosis diagnosis, prevention and treatment practices of pediatric rheumatologists in North America. Pediatr. Rheumatol. Online J. 2014;12:24.

76. Saurenmann RK, Rose JB, Tyrrell $P$, Feldman BM, Laxer RM, Schneider $R$, et al Epidemiology of juvenile idiopathic arthritis in a multiethnic cohort: ethnicity as a risk factor. Arthritis Rheum. 2007;56:1974-84.

77. Ellis JA, Ponsonby A-L, Pezic A, Chavez RA, Allen RC, Akikusa JD, et al. CLARITY - ChiLdhood arthritis risk factor identification sTudY. Pediatr Rheumatol Online J. 2012;10:-37.

78. Thorsen S, Pipper C, Alberdi-Saugstrup M, Nielsen S, Cohen A, Lundqvist M, et al. No association between vitamin D levels around time of birth and later risk of developing oligo- and polyarticular juvenile idiopathic arthritis: a Danish case-cohort study. Scand J Rheumatol. 2016;9742:1-8.

79. Falcini F, Marini F, Rigante D, Bertini F, Lepri G, Stagi S, et al. PReS-FINAL2053: vitamin D receptor polymorphisms in a cohort of Italian patients with juvenile idiopathic arthritis. Pediatr Rheumatol. 2013;11:P66.

80. Ellis JA, Scurrah KJ, Li YR, Ponsonby A-L, Chavez RA, Pezic A, et al. Epistasis amongst PTPN2 and genes of the vitamin D pathway contributes to risk of juvenile idiopathic arthritis. J Steroid Biochem Mol Biol. 2015;145:113-20.

81. Consolaro A, Bracciolini G, Ruperto N, Pistorio A, Magni-Manzoni S, Malattia

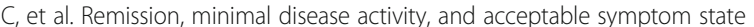
in juvenile idiopathic arthritis: defining criteria based on the juvenile arthritis disease activity score. Arthritis Rheum. 2012;64:2366-74.

82. Giannini EH, Ruperto N, Ravelli A, Lovell DJ, Felson DT, Martini A. Preliminary definition of improvement in juvenile arthritis. Arthritis Rheum. 1997;40:1202-9. 
83. Berkun Y, Lewy H, Padeh S, Laron Z, Centre SM, Hashomer T.

Seasonality of birth of patients with juvenile idiopathic arthritis. Clin Exp Rheumatol. 2015;33:122-6.

84. Carlens C, Jacobsson L, Brandt L, Cnattingius S, Stephansson O, Askling J.

Perinatal characteristics, early life infections and later risk of rheumatoid arthritis and juvenile idiopathic arthritis. Ann Rheum Dis. 2009;68:1159-64.

Ready to submit your research? Choose BMC and benefit from:

- fast, convenient online submission

- thorough peer review by experienced researchers in your field

- rapid publication on acceptance

- support for research data, including large and complex data types

- gold Open Access which fosters wider collaboration and increased citations

- maximum visibility for your research: over $100 \mathrm{M}$ website views per year 